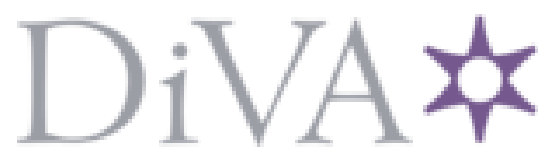

http://www.diva-portal.org

\title{
Postprint
}

This is the accepted version of a paper published in Journal of Retailing and Consumer Services. This paper has been peer-reviewed but does not include the final publisher proof-corrections or journal pagination.

Citation for the original published paper (version of record):

Strom, R., Vendel, M., Bredican, J. (2014)

Mobile marketing: A literature review on its value for consumers and retailers.

Journal of Retailing and Consumer Services, 21: 1001-1012

Access to the published version may require subscription.

N.B. When citing this work, cite the original published paper.

Permanent link to this version:

http://urn.kb.se/resolve?urn=urn:nbn:se:kth:diva-186299 


\section{Mobile Marketing: A literature review on its value for}

\section{consumers and retailers}

Roger Ström ${ }^{1}$, Halmstad University, Sweden

Martin Vendel ${ }^{2}$, KTH Royal Institute of Technology, Sweden

*John Bredican ${ }^{3}$, ISC Royal Holloway, University of London, England

1 Halmstad University

Spetsvinkelgatan 29

SE-302 50 HALMSTAD

Sweden

Roger.Strom@hh.se

${ }^{2}$ Department of Industrial Engineering and Management,

Royal Institute of Technology (KTH)

Lindstedtsvagen 30 ,

10044 Stockholm,

Sweden

martin.vendel@indek.kth.se

Corresponding author:

${ }^{3}$ John Bredican,

Email: John.Bredican@rhul.ac.uk

ISC Royal Holloway, University of London

Wetton's Terrace

Egham Hill Road

Egham, TW20 0EX

United Kingdom

Ph: Mob +44 7799588484

Ph: + 44 (0)20 73742276 


\begin{abstract}
The article describes the existing knowledge of how mobile marketing can increase value for consumers and retailers. Mobile device shopping, and consumers' use of mobile devices while shopping is shown to be both an extension of consumers' shopping behaviours developed on Internetconnected desktop and laptop computers (PC), and potentially new behaviours based on a mobile devices' uniquely integrated features such as camera, scanners and GPS. The article focuses on how mobile marketing creates value for consumers and retailers, enabling more precise research and development of managerial concepts and tools while providing both managers and academics with increased understanding of mobile marketing and it's value outcomes for retailers.
\end{abstract}

Keywords: Mobile marketing, integration, and value creation. 


\subsection{INTRODUCTION}

Mobile devices and mobile applications offer retailers more than just the opportunity to exploit a new channel to reach customers. Mobile devices offer opportunities to combine information search, phone functionality and interaction while shopping in-store or using a product. A mobile device is a constant companion to the consumer, a gateway to a relationship between the consumer and the retailer, making it an ideal supplementary channel for distance selling and physical retailing (Shankar, Venkatesh, Hofacker et al, 2010). An industry study showed that half of US mobile consumers are mobile device shoppers, 10 percent heavy and 40 percent light users (Leo Burnett \& Arc Worldwide, 2011). But mobile devices are different from desktop and laptop computers (PC) due to a limited keyboard and screen size (Mahmoud \& Yu, 2006), and offer functions such as camera, scanners and Global Positioning System (GPS). This makes mobile marketing potentially different from PC Internet and traditional marketing. The Mobile Marketing Association definition of mobile marketing is "a set of practices that enable organizations to communicate and engage with their audience in an interactive and relevant manner through any mobile device or network" [1].

The major impacts of the Internet on retailing are the reduced search costs for the consumer (Bakos, 1997, Lynch \& Ariely, 2000), an increasing variety of products offered (Brynjolfsson, Hu \& Smith, 2003) lower prices (Brynjolfsson \& Smith, 2000), empowering consumers to make better choices for themselves, and increasing the relationship with the purchased brand after purchase (Edelman, 2010). As an example, Court, Elzinga, Mulder et al, (2009) found that $60 \%$ of consumers of facial skin care products conducted online research after purchase. But in purchasing situations when consumers want an experience, a product trial, in-store atmosphere, or interaction with a salesperson, the Internet distance selling falls short of expectations (Daugherty, Li \& Biocca, 2008).

In conceptual studies, the additional value created by mobile services for consumers derived from being accessible independent of time and place (Balasubramanian, Peterson \& Jarvenpaa, 2002, 
Chen \& Nath, 2004), and being customized based on time, location and personal profile (Figge, 2004), self-ascribed roll categories (Professional (on duty), private (off duty)) and stance categories (busy, time on hand, waiting) (Dholakia \& Dholakia, 2004). According to Kumar and Zahn (2003), the real business drivers for mobile technology were customer interaction and operational efficiency, potentially increasing retailer effectiveness and efficiency. Conceptual studies presented suggestions on mobile marketing value chains consisting of several activities performed by multiple actors (Barnes, 2002, Buellingen \& Woerter, 2004), improving communication and sales (Mamaar, 2003, Shankar \& Balasubramanian, 2009). However, the consumer's role as a co-creator of value was neglected in these studies. For instance, Prahalad \& Ramaswamy (2003), sees much of future innovations spurred from consumers involvement in co-creation of value. An assumption is that mobile marketing may serve as a tool for involving consumers in co-creation activities independent of time and place. Value for consumers is then assumed to drive adoption, use and loyalty to retailers' mobile marketing applications, and then affect recruitment and loyalty to the firm.

Based on the above there are some concerns that require discussion. Unexplored questions include: who are the mobile device shoppers, what is the value of mobile marketing for retail consumers, what is the value of mobile marketing for retailers, and how can retailers realise the potential of mobile marketing? The purpose of this study is to describe existing knowledge on how mobile marketing can increase value for consumers and retailers. Value for consumers is assumed to drive adoption, use and loyalty to retailers' firm and mobile marketing applications, and recruitment. These factors create the foundation of competitiveness for retailers (Porter, 1985). This paper will proceed as follows: the methodology of the literature search is presented followed by the literature review. Next, the findings of the review are discussed. Finally, conclusions, managerial implications and implications for further research are presented. 


\subsection{METHODOLOGY}

A preliminary literature search was conducted during April 2010 using the ISI Web of Knowledge database. The literature search was limited to peer-reviewed journals and was based on keywords such as: "mobile marketing”, “m-marketing”, "mobile commerce”, “m-commerce”, "mobile advertising", "m-advertising", "mobile loyalty" and "m-loyalty". The 50 most cited articles were selected (cited five times or more). Several conceptual studies and some best demonstrated practice/output value studies covered topics as mobile value creation and mobile value chains, while a limited number of studies were related to consumer perceived value in mobile contexts.

An additional literature search was conducted during September and October 2011, using the ISI Web of Knowledge database with the above search words in combination with "value", "value chain", "strategy" and "perceived value". A search was also conducted in International Journal of Mobile Marketing and International Journal of Mobile Communications, as the majority of articles covering mobile marketing were published in these journals (Varnali \& Toker, 2010). Assuming differences in consumer behaviour on a more general technology level (devices and services) compared to the specific mobile marketing level, the search was expanded due to the low number of studies. Search words of closely related constructs to perceived value such as "attitude", "perceptions", "satisfaction" and "trust" were used in combination with the search words from the 2010 search. A total of 64 empirical studies were selected for a qualitative content analysis, categorized based on research themes, and then discussed within and between categories. For an overview of the reviewed studies see Table 1-4 in Appendix 1.

\subsection{LITERATURE REVIEW}

In this review, value creation in mobile contexts are described from both a consumers' and the retailers' perspective as the value of mobile marketing for consumers, and the value of mobile marketing for retailers. The value of mobile marketing for consumers is further divided into mobile device shoppers and consumer perceived value benefits and sacrifices of mobile marketing. The value of 
mobile marketing for retailers is divided into the improved value of mobile marketing, and realizing potential value in mobile marketing.

[Insert Figure 1 about here]

\subsubsection{Mobile device shoppers}

Two studies from the Japanese market revealed segments of mobile and fixed internet users (Okazaki, 2007:2, Okazaki \& Romero, 2010). The studies were based on surveys only. Adding mobile Internet clickstream data to the surveys would have increased the knowledge of the segments detailed usage of mobile Internet and may have resulted in even more narrow segmentation models. Though the studies identified segments of different usage levels of mobile pull advertising users, it revealed limited knowledge about mobile device shopping behaviours.

Mahatanankoon et al (2005), identified valuable m-commerce operation modes and potential consumer-based applications. Applications of a certain interest for mobile device shoppers seemed to be content delivery (searching and receiving information about retailers, assortments, brands, prices etc), transaction-based (order and payment services), location based (receiving personalized, location based and time sensitive offers, advertising, map and route to closest store (GPS Location), finding products in-store and usage instructions). Other mobile functions, potentially valuable for mobile device shoppers, may be memory support (shopping lists, pictures of products and brands and bookmarks on web browsers), administration of loyalty benefits, and sharing of information and content. This additional functionality drives different behaviours as there are more uses for the device as compared to a PC or Internet website. The camera function used for comparing products, scanning, or using GPS location or using apps that augment the experience and provide additional information. So, at times it could be a companion to another channel, for example the retail store; or it could be the channel that a user is most engaged with at the time. The value lies in providing a satisfying experience. 
Okazaki (2007:2) suggested that Japanese mobile Internet users could be classified into three segments in terms of their demographics and life-styles. The literature also indicated that mobile device shoppers might be further segmented based on multiple variables (Table A1). The only segment that seemed to fit into the classification of mobile device shoppers were students and young unmarried office workers, as they exhibited higher usage of mobile Internet and using mobile pull advertising to a higher degree to search for new information.

Okazaki and Romero (2010) also identified segments of dual Internet media users. Four different Internet user segments in the Japanese market were identified: segments of moderate fixed and mobile Internet users, heavy fixed Internet users, and two segments of heavy mobile Internet users. Among the heavy mobile Internet users one segment were also heavy dual Internet users, while the other segment only used Fixed Internet moderately. The dual Internet users were of certain interest as it indicates that mobile device shopping was a learnt behaviour from fixed Internet PC, and potentially developed by other mobile experiences (Table A1). The results from Okazaki and Romero (2010), also indicated that PC Internet might be used for recruitment of mobile device shoppers in markets with high fixed Internet penetration and high fractions of dual media users.

\subsubsection{The value of mobile marketing for consumers}

Value is the benefits offered by the product or service compared to customer sacrifices for acquisition and use of the product and service relative to competition (de Chernatony, Harris \& Dall'Olmo Riley, 2000, Ulaga, 2003, Walter, Ritter \& Gemünden, 2001, Zeithaml, 1988), and differs based on consumer product experiences (Parasuraman, 1997). Perceived value affects acceptance and use of mobile technology, services and marketing and loyalty to mobile services and marketing (Table 1). In several studies related to mobile marketing value for consumers, perceived value was not explicitly measured. But the majority of the studies measured components of benefits and sacrifices. Studies of consumer mobile marketing adoption used the Technology Acceptance Model (TAM) by Davis ((1989), the Theory of Reasoned Action (TRA) by Fishbein and Ajzen (1975)), the Theory of 
Planned Behaviour (TPB) by Fishbein and Ajzen (1975), and Rogers (1995) innovation attributes. Studies of consumers' mobile advertising use were mainly based on Media Gratification Theory (Atkin, 1973), adopted to mobile media (Tsang et al, 2004) and affecting attitudes, mobile media behavioural intent and behaviour. The TBP model included evaluations of benefits and perceived risk, media uses and gratifications theory (Okazaki, 2007:2), included media benefits and perceived irritation. In some perceived value studies a similar construct to ease of use in the TAM model was used as a sacrifice construct (Kleijnen et al, 2009).

\subsubsection{The perceived value of interactivity in mobile contexts}

The perceived value of mobile marketing for customers were based on the additional value complementing or substituting PC Internet (Okazaki \& Hirose, 2009) in user situations where PC internet is not accessible or practical to use, for example by adding interactivity to promotions, channels and products by mobile marketing (Sultan \& Rohm, 2005). Interactivity is defined as different forms of interactions between individuals and groups either directly or mediated through digital platforms or media. The degree of interactivity is defined through the degree of two-way communication, synchronism and participants' active control over the experience (Liu \& Shrum, 2002). For mobile contexts Gau, Rau and Salvendy (2009), proposed additional of constructs such as connectedness (being linked to more resources), playfulness and interpersonal communication (communication taking on some characteristics of interpersonal communication). Results show that increased response options in mobile push advertising, increased playfulness and customization options in mobile game advertising, resulted in increased perceived interactivity and positive attitudes towards mobile push advertising and game advertising. The results also imply that the higher perceived interactivity in mobile communication the better (Gau et al, 2009). This may be relevant for game and content providers and to some extent for mobile push media, the least interactive mobile media. But for retailers who have to balance between supplying customers with enough information to fill their information needs, and then minimizing interactivity to increase 
conversion, this view needs to be modified.

\subsubsection{Perceived value, consumer's goals and retailers outcome value}

When measuring the effects of interactivity on consumer perceived value, an important factor is to consider what goals consumers have when using interactive functions. As an example, Moe (2003) found that the average conversion rate for an e-commerce site was $1.25 \%$. Using clickstream data (customers' navigation traits on a web site) and clustering customers based on their goals from visiting the site, five different customer segments were identified based on if their search behaviour: First, goal directed immediate purchaser, second, goal directed future purchaser, third, hedonic immediate purchaser, fourth, hedonic future purchaser, and finally, just landing on the website and then directly leaving, so not considered to be as customer at all. As a consequence of consumers' different goals visiting the site, the conversion rate varied. Goal directed customers considering a more or less immediate purchase had a conversion rate between 8 to $13 \%$, while hedonic browsers had a conversion rate of $2 \%$. These results indicate that retailers' need to measure the quality of visitors to their web site and customize content, design and interactivity based on consumers' goals, interests, product and brand experiences, and loyalty. The perceived value for consumers to be loyal to a website appears to come from learning effects, reduced perceived trust and trust in retailers' website. If this kind of "stickiness" of websites is valid for retailers' mobile marketing, then consumers' accumulating use may potentially and gradually improve consumers' brand relationships, traffic to store, and purchasing volumes.

Media Gratification Theory (Atkin, 1973), considers customers having different motives, utilitarian

or hedonic, when using a media. As an example the most cited studies of consumer adoption of mobile device and service, were highlighting the importance of utilitarian benefits and hedonic constructs of fun (Bruner and Kumar, 2005, Nysveen et al, 2005) and expressiveness (Nysveen et al, 2005). Most of the reviewed studies also verified that customers perceive utilitarian or hedonic 
values (or value tendencies or benefits) based on their goals using mobile services (Table A). The majority of the studies focused on mobile push advertising use (Table 4), the least interactive mobile media. The starting point for these studies are that customers are more or less forced to be exposed to mobile push advertising, and then the perceived values of these forced exposures were measured. Fewer of the reviewed studies focused on mobile pull media as mobile Internet (Table 4). Neither of these studies considered consumers individual goals based on interests, category and brand experiences, nor was the time frame of conversion and loyalty considered. As a consequence the path between consumers' individual goals, perceived value and retailers' outcome value were not verified in mobile contexts.

\subsubsection{Consumer perceived values, benefits and sacrifices of mobile marketing}

Several results verified mobile service values or benefits as utilitarian, emotional, social and monetary value. A few comparative studies revealed results about which perceived values that affect consumer preferences for mobile media compared to PC Internet (Table A and B). For mobile services perceived values varied based on situational value and novelty value. Situational value affected utilitarian, emotional, social and monetary value, while novelty value only affected emotional and social value for both information and entertainment services, and monetary value for information services (Pilström \& Brusch, 2008). The relative importance of perceived utilitarian and emotional values also seemed customer segment and category specific (Table A). In this early stage of retailers' mobile marketing implementation, the perceived values and benefits of mobile marketing may affect retailers' brand positioning according to the results of Okazaki et al (2007).

\subsubsection{Perceived utilitarian values and benefits}

The major, but not always the dominating importance of utilitarian values and benefits in mobile contexts were shown in several studies contributing to the adoption and use of mobile devices, services and marketing. Convenience value was important for the use of utilitarian mobile retail 
categories as financial services and consumer loyalty to information services. Content reliability and quality also had a strong effect on loyalty to mobile services and marketing. Convenience value and content relevance could be increased by customization, making mobile services and marketing less cumbersome for consumers to use. Customization also affected adoption, use, purchase intentions of mobile marketing (Table A). According to these results, retailers' use of clickstream data, personal profiles and customer purchase history with mobile marketing may increase customization, convenience value, and potentially increase the competitiveness of retailers' mobile marketing over time, creating loyalty to retailers' mobile marketing. Another example of simplification of data input methods is Japanese firms' adoption of quick response industrial codes (QR codes). By scanning this code, customers could automatically jump to a target mobile web site without typing in the full web address (Okazaki \& Romero, 2010).

For mobile push advertising credibility was the most important utilitarian benefit affecting adoption and use, with less important weight on content relevance. Information and credibility were the most important benefits affecting use of mobile pull advertising. The importance of credibility on consumer use of mobile advertising, created advantages for well-known brands, and in existing consumer relationships, or if consumers' had trust in mobile advertising (Table A).

\subsubsection{Perceived emotional values and benefits}

The major importance of emotional values in mobile contexts were highlighted in several studies affecting adoption and use of mobile services and devices, and loyalty to entertaining and enjoying mobile services. The relative importance of entertainment benefits on adoption and use was category specific; hedonic categories and mobile pull advertising. But entertainment benefits were not as important for mobile pull media, though interactive and/or multimedia advertising were perceived as more informative, entertaining and less irritating. Emotional values were realized in different manners in mobile contexts (Table B). 


\subsubsection{Perceived social values and benefits}

Social values effect on adoption and use of mobile services showed discrepancies. Some results indicated low significance of social values effect on adoption and use of mobile services. Instead social benefits and values seemed to influence adoption and use indirectly. Other results showed perceived social usefulness had a major impact on perceived usefulness for SMS advertising. Subjective norms had a significant positive effect on adoption intent on mobile marketing in a few studies. Social value also had some affect on consumer loyalty in terms of word of mouth and willingness to pay premium prices, especially for entertainment services (Table B).

\subsubsection{Perceived sacrifices}

The main sacrifices for consumers to adopt and use mobile services and marketing were surprisingly not perceived risks, except for more advanced mobile device shopping behaviours, such as mobile device distance shopping and information disclosure in Location Aware Marketing (LAM) systems. Instead efforts to learn and use the mobile services and marketing were the main sacrifices for consumers (Table B).

The importance of monetary costs on perceived value of mobile services differed. Monetary costs did not appear to dominate perceived value orientations in the mobile field, except for in studies using samples dominated by students (Table B). As previous results indicated that mobile device shoppers seemed to be more affluent, monetary costs for mobile services may be assumed to have a lesser impact on these consumers' value perceptions. For more price-sensitive consumer groups' mobile service costs can be a barrier to adopt a mobile device shopping behaviour.

Perceived irritation was the main sacrifice affecting mobile advertising use, especially for mobile push advertising (Carroll et al, 2009, Okazaki, 2007:2, Tsang et al, 2004). Comparing MMS with SMS, multimedia appeared to have positive effects on informativeness and entertainment. But perceived irritation was higher for multimedia push advertising (MMS) because of distraction and 
cognitive overload (Xu et al, 2009), partly contradicting the results of Cheng et al (2009), who found MMS less irritating than SMS. Integration of SMS and multimedia pull advertising as mobile websites, seems like a straight forward approach to minimize consumer irritation of mobile pull advertising while combining multimedia effects on informativeness and entertainment.

Consumers' negative perceptions of mobile push advertising could be changed if permission was obtained, or if service provider filter messages. Frequency of messages received also effected perceptions of mobile push advertising, as timing of messages, increasing content relevance through personalization, or if the advertisements were sent from a friend or community. Finally, the value perception of mobile push advertising and intentions to receive mobile push advertisements could increase by adding incentives (Table B).

\subsubsection{Comparative perceived values and benefits}

Consumers perceived media image and gratification opportunities differently, this explains consumer's preferences for one media compared to others (Okazaki \& Hirose, 2009, Okazaki \& Romero, 2010). Mobile Internet users perceived mobile devices as enjoyable and timely, recognizing their three primary benefits: convenience (flexibility in terms of time and location), companionship and efficiency compared to the PC. Media switching between mobile and PC Internet could be explained by the mobile Internet functioning as a complementary media to fixed Internet in high involvement situations, while mobile Internet functioned as a substitute in lower involvement situations.

Efficiency, convenience and safety were the most important benefits determining differences in customer value perceptions between PC Internet and mobile devices in banking. Due to the limited keyboard and screen size of the mobile device, Internet banking provided higher convenience in dimensions related to speed, ease of service use and safety aspects as uncertainty in service consumption compared to mobile banking. Convenience and safety aspects called for simplification 
of data input methods, when the service was used via a mobile device. Mobile banking is perceived as more efficient based on service access independent on time and place. It enables immediate action, saves time, which are valuable benefits for time conscious consumers. For self-service consumers, user control over the service delivery process affected utilitarian value perceptions (Table B). For time conscious and self-service consumers mobile financial services increased value, meaning that consumers could be segmented based on service level and channel preferences in the service delivery process (Kleinen et al, 2009), potentially increasing satisfaction and brand loyalty.

\subsubsection{The value of mobile marketing for retailers}

According to Porter (1985) value from the firm is represented by a series of activities and processes, a value chain, providing the given level of value for consumers. The value the firm can create for its consumers helps form the foundation for the firms' competitive advantage, resulting in higher margins. Sustainable competitive advantages built on substantial, scarce or unique resources and competences integrated in the firms' value chain create barriers for direct competition. Mobile marketing is assumed to function as a tool improving activities in retailers' value chain, indicated to improve consumer communications, service interactions resulting in improved output value and potentially higher margins. The improved output value was both related to transaction-based results as traffic to stores and sales, and brand relationship results in brand awareness, associations, attitudes, purchase intentions and loyalty. Results also indicated the potential to increase service quality, perceived value and satisfaction using mobile marketing in-store during service interactions, creating the foundations for increasing consumer loyalty to retail brands. The loyalty effects of mobile marketing were, however, less studied (Table C). If consumers' post purchase interactions with purchased brands are a contact point of increasing importance strengthening the consumer and brand relationship, then mobile marketing may become an important tool for consumers supporting such interactions. Further, if loyalty also spurs consumers' willingness to 
participate in viral mobile marketing, the viral effects may serve as one out of several indicators of consumer loyalty. The viral effects may also result in increased branding and sales effects, both decreasing contact costs, while the willingness of receivers to access viral content is higher than for firms' mobile push advertising.

Retailers' perceived values of mobile marketing are based on outcome benefits, process benefits, and monetary and non-monetary sacrifices. Retailers' adoption and use of m-advertising services differed by how they perceived benefits, and value and differences in user's participation in value co-creation. The more the users participated the more value they seemed to perceive. Finally, retailers' adoption and use of m-advertising services differed based on cultural differences measured as nationality. Firms' perceptions of how improved outcome value could be achieved by mobile advertising, came from the use of location based marketing supporting the branding strategy, and were depending on facilitating conditions, restrained by security or privacy issues and costs (Table C). The analysis of consumer perceived value confirm that mobile marketing supports consumer processes as pre-purchase, service interactions and sales in mobile channels. Studies based on a firms' perspective were focusing on mobile marketing as an advertising tool with two exceptions (Table 4).

\subsubsection{The improved value of mobile marketing}

Lee, Cheng and Cheng (2007), regarded mobile marketing as a tool for front-line staff improving person to person interactions between insurance agents and consumers, defined as internal mobile marketing. Based on these results the potential value of mobile marketing for retail front-line staff include: increased efficiency and effectiveness in service interactions, increased work capacity and service quality, and increased capacity to match consumer needs by providing information services about products and product use. Using the same logic, in-store mobile marketing to self-service consumers may increase effectiveness and efficiency of service interactions, limiting the need for 
staff interactions while still completing transactions of high-perceived value.

Nysveen, Pedersen and Berthon (2005) verified mobile push media as a tool to improve consumer brand relationships between purchases or interactions. These are measured as brand satisfaction and relationship investments. Even more interesting for retailers was that mobile push communication also fostered main channel use. By adding mobile marketing, retailers may increase loyalty to a store network, using mobile push media to drive traffic to mobile pull media, as the higher interactivity and media richness were more effective creating category and branding effects (Table C).

Several studies covered mobile advertising effectiveness, the outcome value of marketing activities in the value chain, mobile push advertising, mobile pull advertising, and cross-media effects of mobile push and Internet pull advertising (Table 4). Results indicated improved outcome value, requirements for realizing these values and a few indications of relative improved outcome value of mobile advertising (Table C). As a consequence there is a knowledge gap covering the effects of instore and post-purchase mobile pull marketing. Another gap is the indirect affect of mobile marketing on other activities in the retailers' value chain. For instance, possibilities to increase campaign frequency may increase the demand for improved purchasing and logistics.

Early results showed high acceptance of mobile pull advertising (SMS), response rates, and purchase intentions, by far exceeding the results of direct marketing, while the branding effects were more moderate to low. Mobile push media may substitute traditional direct marketing investments to some consumer segments increasing communication effectiveness for high and low involvement categories for both products and services. Mobile pull media showed high interest in category and branding effects (Table C). This points to a need for greater integration of mobile pull media with mobile push media. 


\subsubsection{Mobile marketing integration}

In a limited number of studies the importance of integrated marketing communication is highlighted

(Table C). Reasons for cross media integration were consumers' increased engagement in processing messages, as they perceived stronger message strength from the messages and exhibited stronger brand attitude with enhanced media engagement (Wang, 2007). Note that Wang (2007), evaluated cross-media integration between SMS messages and PC Internet website, and similar cross-media effects are probably achieved by integrating mobile push and pull media. These results indicated stronger effects on brand perceptions among consumers integrating mobile push and pull advertising, and a potential for increasing consumer recruitment and loyalty. Examples of successful integrated mobile marketing were improving category and brand building, driving traffic to store, increasing sales, while outperforming off and on-line advertising (Kim \& Jun, 2008). Suggestions to integrate mobile media with off and on-line media (Sultan \& Rohm, 2005), created opportunities to capitalize on traditional medias' high reach and impact with mobile medias' possibilities to interact with individuals and thus drive traffic to store. For higher involvement categories, mobile media integration with low location dependency media (TV, magazines, PC Internet) may be suitable, as it can support more planned purchasing behaviours, while integration with high location dependency media (billboards, out of home media use) may be more suitable for less planned purchasing behaviour, or for purchasing behaviour where choice of brand or retailer is decided close to purchase. Suggestion to integrate products, packages and mobile marketing to support consumers' decision making in-store and influence sales with in-store mobile coupons (Sultan \& Rohm, 2005), may be valid for post-purchase interactions supporting consumers' use and knowledge of products and brands.

\subsubsection{Realizing potential value in mobile marketing}

To summarise previous chapters mobile marketing seems to add most value to mobile device shoppers and retailers if it is fully integrated in consumer interfaces, adding interactivity to all 
consumer contact points or substituting some contact points with mobile marketing. In this case, and previously discussed, retailers' marketing strategies may be affected, such as segmentation and targeting, market communication and channel integration. Mobile marketing may also affect brand image and positioning, offerings, assortments and prices, however less covered by the reviewed studies.

Instead a limited number of studies presented findings on describing best demonstrated practice on how to implement successful mobile advertising from a single media or channel perspective, and how firms could realize potential in mobile marketing, and resources and competences to facilitate such actions. Results indicated the need for structural changes of partner networks (technology and content providers, consultants etc.), organizations and IT-structure for retailers to fully capitalize on the potential of mobile marketing (Table C). As these results are based on mobile advertising, the general need for combining resources and capabilities are likely to be similar for in-store and post purchase marketing. But the literature revealed less about if other kinds of partners, resources and capabilities are needed in the network.

However, driving consumers to mobile marketing will potentially increase transparency of retailers' online and in-store product offerings and prices and this may increase consumers' migration to cheapest alternative. A relationship not covered by the reviewed studies concerns the situation where if increased transparency increases consumers' migration to cheaper alternatives, and this in turn increases industry competition.

Success factors for mobile advertising (SMS) campaigns, and potentially for post-purchase push communications, were related to message content, management of media issues as device development, fluctuating quality of transmission processing, product fit and media costs, measurement, and global campaign launch strategies (Table C).

For managing consumer heterogeneity, mobile marketing needs to be personalized or at least 
require narrow segmentation. Retailers need to integrate consumer databases (Sultan \& Rohm, 2005) and mobile platforms with back-end solutions to take full advantage of the mobile marketing. Context-aware mobile advertising needs to be planned locally rather than headquarter or centrally planned traditional media campaigns (Komulainen et al, 2007). For internal mobile marketing, staff computer self-efficacy was found to be the major factor impacting the task-technology fit, while education, position experience, and cognitive style are found to impact certain factors of the tasktechnology fit (Lee et al, 2007). Results were similar to consumer acceptance and use of mobile marketing, requiring an update of competence profiles, experiences and knowledge of retailers' staff, as well as the ability to manage for instance context-aware mobile advertising.

\subsubsection{Mobile marketing metrics}

Mobile marketing provides retailers with an additional marketing tool, and in so doing creates a need for structural change, and the need for adequate measurement of mobile marketing effectiveness is imperative. But commercial effectiveness of m-advertising was often evaluated in the same terms as traditional media (Komulainen et al, 2007). An integration of traditional and nontraditional measures is needed (Li \& Stoller 2007). Based on Sultan and Rohm (2005) and Rettie et al (2005), measures for mobile test media (SMS) should include: brand awareness, consumer responses at the retail or transaction level, as well as the viral effect of mobile-marketing messages. Based on Bellman et al (2011), the evaluation of mobile multimedia such as mobile web and apps should also include other brand measures such as brand attitude and purchase intention. We posit that additional measures might also be included such as store effectiveness, by looking at conversion rates, up-sales, cross-sales, customer value and satisfaction. With a similar logic, retailers' mobile marketing that supports customer post purchase brand interaction and product use may include measures of loyalty effects (attitude as behavioural based loyalty), value of and satisfaction with product use and support. For mobile pull media, the quality of the visitor base may directly affect the expected results of their visit, so a special focus might look at measuring the 
effects based on what customers' visit the media and their individual goals with the visit.

\section{DISCUSSION}

Mobile device shoppers could represent substantial value for retailers due to their higher spending power (Barutcu, 2007, Okazaki, 2007:2), even though their mobile shopping behaviours were far from explored. Mobile device shoppers may be considered as multiple segments (Okazaki, 2007:2, Okazaki \& Romero, 2010), further segmented, based on at least gender (Constantinou \& Mahnke, 2010, Deng et al, 2010, Okazaki, 2007:1), age (Barutcu, 2007, Deng et al, 2010), and cultural differences (Choi et al, 2008, Constantinou et al, 2009, Dai \& Palvia, 2009, Muk, 2007). Differences between existing and potential mobile device shoppers were not identified in the reviewed literature.

However, indications were found that mobile device shoppers were both experienced mobile device users (Alda's-Manzano et al, 2009, Roach, 2009), and consisted of high fractions of savvy PC Internet users (Alda's-Manzano et al, 2009, Deng et al, 2010, Kleinen et al, 2009, Lin \& Wang, 2006, Lu \& Su, 2008, Okazaki, 2007:1). These consumers also had higher knowledge and selfefficacy (Moynihan et al, 2010), exhibited an exploratory search behaviour (Wang \& Acar, 2006), was more involved and/or more price-conscious, and had an higher education (Barutcu, 2007). In summary these results may indicate that mobile device shopping is an extension of Internet shopping behaviours, potentially developed through experiences using specific mobile device functions, such as camera, QR code scanners and GPS.

Targeting mobile device shoppers require retailers to manage these consumers to opt-in to retailers mobile marketing from multiple contact points, due to the downsides of mobile push channels (Bauer et al, 2005, Carroll et al, 2009, Dickinger \& Kleijnen, 2008, Peters et al, 2007, Tsang et al, 2004). The downsides of mobile push channels also limited communication frequency and choices of target groups to consumers with high brand awareness (Carroll et al, 2009), especially existing 
customers (Peters et al, 2007) permitting to receive mobile push advertising, and by assumption during campaign periods when brand awareness increase. Based on Kleinen et al (2009), mobile marketing also offered opportunities for retailers for segmentation and targeting of consumers instore and for post-purchase services, improving perceived value, and potentially retailers' outcome value based on Lee et al (2007). However, to make consumers opt-in to mobile marketing is just the starting point of managing consumer relationships with mobile marketing. How consumers may be segmented, targeted and managed by customized interactions in real time during different stages in brand relationships were not comprehensively covered by the reviewed studies.

Mobile marketing delivered utilitarian, hedonic, social and monetary values to consumers (Kim et al, 2007, Pilström \& Brusch, 2008, Turel et al, 2007, Yang \& Jolly, 2006). The relative importance of each value or benefit construct differed between mobile media or channel types (Bauer et al, 2005, Choi et al, 2008, Chowdhury et al, 2006, Haghirian \& Inoue, 2007, Okazaki, 2007:2, Tsang et al, 2004, Xu, 2006), utilitarian or hedonic categories (Kim et al, 2009, Lu \& Su, 2008, Pilström \& Brusch, 2008), and contexts (Pilström \& Brusch, 2008). However the reviewed literature revealed less about how consumers use mobile media and channels, PC Internet and store network for shopping, and what value each type of channel in different shopping contexts delivered. Mobile channels may be preferred by consumers in certain shopping situations that create higher emotional values such as filling spare time (Peters et al, 2007), while being remote from a PC or in situations were a PC is unpractical to use, such as travelling, on coffee brakes; or while consuming traditional media (Peters et al, 2007). Other potential situations are when consumers are on the go and external stimuli are arousing interest for specific content, when close to and during store visits, or during product use. In these situations, mobile channels may deliver higher utilitarian values, such as efficiency (Kleinen et al, 2009, Laukkanen, 2007), and time and location convenience (Kleinen et al, 2009). For information search in higher involvement categories, PC Internet was preferred (Okazaki \& Romero, 2010) due to screen size, easier navigation and data input (Laukkanen, 2007), 
and as an alternative to stores for completion of transactions.

Mobile marketing may be an adequate tool for retailers to use in lower involvement categories and as a complement to PC Internet in higher involvement categories (Okazaki \& Romero, 2010). Eventually, the development of mobile devices and interfaces will affect consumers using mobile Internet to a greater extent in higher involvement situations. In summary, mobile marketing may be perceived differently in different shopping contexts, resulting in different effects on retailers' outcome value. Even though social values did not directly effect adoption, and use of mobile marketing, it had a minor affect on loyalty (Muk, 2007, Pilström \& Brusch, 2008, Zhang \& Mao, 2008). Retailers should not underestimate the potential importance of social values in creating loyalty effects as word of mouth or viral marketing (Wais \& Clemons, 2008). Social values of mobile channels may be more important for emotional categories (Pilström \& Brusch, 2008), as consumers may feel a need for social approval for, or supporting social status of brand and product choices.

Realizing the potential value of mobile marketing for consumers and retailers, mobile marketing was indicated to add most value if it is integrated in consumer interfaces, adding interactivity to existing consumer contact points or substituting some contact points with mobile marketing. A limited number of studies highlighted the importance of integrating mobile marketing communication (Kim \& Jun, 2008, Scharl et al, 2005, Sultan \& Rohm, 2005), integration of PC and mobile Internet (Okazaki \& Hirose, 2009, Okazaki \& Romero, 2010, Wang, 2007), integrating mobile marketing with traditional media (Kim \& Jun, 2008). The Suggestion to integrate mobile marketing with products and packages (Sultan \& Rohm, 2005), makes mobile marketing a part of the augmented product. To support consumers' opt-in to retailers' in-store mobile marketing, promotion material in-store may need to be integrated with mobile marketing. As a consequence mobile marketing may be fully integrated in retailers' consumer interfaces to reach its full potential. 
The effects for retailers of such an integration of mobile marketing may be increased effectiveness of brand communication, and improved service interactions instore and post purchase. Rettie et al (2005), verified increased outcome value of mobile push advertising compared to direct marketing for firms, while integration of mobile push and pull advertising outperformed traditional advertising (Kim \& Jun, 2008). Lee et al (2007), presented a study of front line staff using internal mobile marketing that indicated increased outcome value for retail. As a channel addition, mobile push advertising could increase loyalty to main channel (Nysveen, Pedersen \& Berthon, 2005), while mobile pull media increased branding effects (Bellman, et al, 2011, Li \& Stoller, 2007), the foundations for increased loyalty to retailers. As consumers' information processing were indicated to be improved by mobile marketing integration (Wang, 2007), consumers' information processing of existing brand contact points may be improved by adding interactivity through mobile marketing. Retailers participating in value co-creation with mobile advertising services providers indicated that increased co-creation activities from retailers' side increased their perceived value of mobile advertising services. The effects of consumers' participating in value co-creation were not covered in the reviewed literature.

Based on Okazaki et al (2007), adding mobile marketing seemed to affect retailers' brand positioning, but how mobile marketing values affected brand associations and positioning the literature revealed less about. It can be inferred that retailers' mobile marketing may contribute to an enhanced experience of retailers existing brand image or adding new, valuable benefits to the brand image, if they are perceived as relevant and superior to what competitors' can offer, and then creating more lasting competitiveness.

By just adding mobile marketing the perceived values and benefits of mobile marketing may affect retailers' brand positioning and images in these early stages of retailers' mobile marketing implementation. For more lasting competitive advantages, retailers may need to identify application areas of high relevance for consumers that may contribute to an enhanced experience of retailers 
existing brand image or by adding valuable benefits to the brand image, and then implementing them in such manners that they are perceived as superior to competitors'.

Driving consumers to mobile marketing may result in increasing loyalty to retailers' mobile marketing based on consumers' higher perceived relative values (Kleinen et al, 2009, Laukkanen, 2007, Okazaki \& Hirose, 2009, Okazaki \& Romero, 2010) and assumable "stickiness" of mobile marketing. Based on the results of Nysveen et al (2005:1) showing that mobile marketing addition were indicated to increase loyalty to main channel, retailers may need to manage consumers' migrations between channels, driving consumers to the most valuable channel in each situation. Preferably, this is done in such manners that it fosters consumers' to use single retailer's mobile marketing as the premium tool supporting planning, purchasing and enhancing brand and product experiences. By providing the most streamlined, customized purchasing and product use processes, and /or the most tempting brand, store or product experience, mobile marketing may foster loyalty to single retailer's store network. A first step may be to identify different roles and synergies between media and channels supporting such interactions on consumer segment levels. This area is comprehensively less covered by the reviewed studies.

The potential downsides of driving consumers to mobile marketing may be the increased transparency of retailers' assortments and prices even in-store. Such transparency may increase consumers' migration to cheapest alternative and increase industry competition. To avoid increasing competition, retailers may also have to reconsider generic strategies (differentiation, low cost or focus strategies), and its effects on total offering, assortments and pricing strategies.

For retailers to develop a mobile marketing value chain, they had to manage a partner network (Salo et al, 2008, Sultan \& Rohm, 2005), structural changes of IT-structure (Sultan \& Rohm, 2005) and organizations based on Komulainen et al (2007). These results implied that mobile marketing implementation may be a major change project, requiring network partners not only to contribute to 
retailers' outcome value but to process benefits and reduction of non-monetary sacrifices, considering retailers' participation in value co-creation (Komulainen et al, 2007) and cultural differences (Okazaki, 2005). These results imply high degree of customization of partner solutions and processes, and development of structural bonds between network partners. The evaluation of mobile marketing was problematic, lacking established measures for the effectiveness of mobile marketing (Sultan \& Rohm, 2005), especially for other application areas than mobile advertising. Mobile marketing also provides retailers with contextual consumer data on an individual level, potentially fuelling retailers with additional data to improve actions and results, however less studied.

\section{CONCLUSIONS}

The purpose of this literature review was to describe existing knowledge on how mobile marketing can increase value for consumers and retailers. The review revealed multiple supports for mobile marketing increasing perceived value for consumers and outcome value for retailers. However, only a limited number of studies supported mobile marketing as more effective than retailers' alternative marketing investments, delivering higher relative perceived value to consumers and higher relative outcome value for retailers. Though not verified, several studies indicated the path between consumer perceived values of mobile marketing affecting adoption, use and loyalty to retailers' mobile marketing, and increasing relative outcome value of retailers' mobile marketing. Mobile marketing may initially support consumers' and retailers' interactions during pre-purchase, service delivery instore, and post-purchase, but to a lesser extent mobile transactions as consumers perceived them as more risky. An interesting aspect was that mobile marketing seemed to increase retailers' outcome value of existing media choices, channels, assortments, and services by the effects of channel addition and integration.

The reviewed literature revealed limited knowledge about mobile device shopping behaviours, restricted to mobile advertising and retail services usage. Mobile device shoppers may be considered 
as multiple segments and potentially valuable to retailers, due to higher income and/or education. Knowledge of effective segmentation approaches for these consumers were limited to traditional background data. Mobile device shopping was indicated to be an extension of PC Internet shopping behaviours. Mobile marketing delivered multiple perceived values to consumers (utilitarian, emotional/entertainment/ hedonic and social values), and relative benefits and values of mobile devices (enjoyable, timely and offered companionship) and marketing (efficiency, time and location convenience) compared to PC Internet. However, mobile device shopping as 'an extension of PC Internet shopping' is somewhat limiting as new behaviours have become evident such QR and bar code scanning, and location based services, while potential new behaviours may be influenced by augmented reality based content and Near Field Communication (NFC) mobile device payment. These values and benefits may be perceived differently dependent on shopping context, and seemed to have some effect on retailers' brand positioning.

Several studies supported the logic for integration of all retailer consumer interfaces with mobile marketing, maximizing exposure and connectivity between retailer and consumer, managing consumers' cross media and channel use, supporting self-segmentation of consumers, increasing perceived value to consumers and outcome value for retailers. The research suggested that the implementation of mobile marketing forms part of the foundation for sustainable competitive advantage. From a branding perspective mobile marketing was indicated to offer several advantages for retailers. First, mobile marketing was indicated to be a more effective channel for brand and sales driven communication than traditional media, sales promotion and direct marketing. Second, by offering opportunities to streamline, customize and enhance shopping experiences in-store, product use and other post purchase interactions, the service experience may reach new levels of perceived values and satisfaction. These new levels of "customer delight" may add to the brand image fostering loyalty and increasing recruitment of consumers. Third, mobile marketing was found to increase the value of existing marketing investments. By channel addition mobile marketing increased connec- 
tivity to retailers and was indicated to increase loyalty to store network. By adding interactivity to existing brand contact points, consumers' information processing were indicated to be improved, resulting in improved branding effects. Finally, as these potential advantages were backed up by development of a partner network and assumingly structural bonds within partner networks and structural changes of IT-structure and organization, the potential for these advantages to be more lasting are increasing. Assumingly, increased consumer co-creation activities by using mobile marketing also increase perceived value for some consumers and outcome value for firms, potentially creating higher brand involvement, loyalty and structural bonds to retailers' and more lasting competitiveness.

\subsection{Managerial implications}

Mobile marketing implementation may be a tactical decision, adding another media to improve single media effectiveness. But the potential of mobile marketing seems to be in the integration with entire consumer interfaces. Mobile device shoppers may be valuable segments for retailers. By optin to retailers' mobile marketing they may be even more valuable. Retailers can deliver higher perceived value to these consumers, potentially affecting recruitment, loyalty and sales results. By optin to retailers' mobile marketing individual consumers are identified, behaviours traceable, perceptions, actions and relationships are more effectible, maximizing retailers' exposure and connectivity independent of time and place, and increase the value of existing marketing investments.

For retailer's that rely primarily on their store network, mobile marketing may seem like a Gordian Knot. Mobile marketing seems to offer opportunities for increased consumer connectivity to retailers potentially offering sustainable competitiveness and increased outcome value. On the other hand it demands substantial resources for change processes, while mobile marketing may increase price competition from competing retailers and distance sellers encountering the physical environment [2]. The worst-case scenario is consumers using retailers' shop network as show rooms, and then use mobile devices to buy from the cheapest alternative on spot, in store. This scenario is probably 
more likely for retailers in higher involvement categories offering supplier branded products without exclusive distribution. Mobile marketing may then affect other strategic decisions for retailers'. An alternative approach to an overall structural change implementing mobile marketing, is identifying application areas with high impact on consumer perceived and retailers' outcome value, requiring minimum investments and organizational changes, stepwise moving on to more demanding application areas while learning the new technology and consumer shopping behaviours.

\subsection{Implications for further research}

The reviewed literature provides a limited contribution to evidence that consumer perceived value of mobile marketing affected retailers' outcome value, and that mobile marketing increased relative value for retailers and consumers. Several key areas calling for further research have emerged. These are listed under four headings: mobile device shopping, the relative outcome value of mobile marketing, mobile marketing value creation, and mobile marketing metrics.

5.2.1 Mobile device shopping - There is a need to know more about the following:

1) What kind of mobile device behaviour consumers' use while shopping,

2) Why they use a mobile device,

3) Which devices they use,

4) In what context(s) they use mobile devices,

5) The levels of mobile usage,

6) What media is consumed?

7) The level of channel switching and what drives this behaviour, and

8) More detailed consumer information.

Such knowledge can be used to estimate diffusion patterns of such behaviours and to identify new usage of and increase the usage of existing mobile device shopping. 
5.2.2 The relative outcome value of mobile marketing - There is a lack of studies measuring the relative outcome value of mobile marketing. Of interest is aligning consumer-perceived value with outcome value of mobile marketing. In general, the lack of comparative results measuring effects of mobile marketing compared to retailers other investment opportunities remains problematic, as evidence by improved relative output value of mobile marketing in the review was found to be one of the major factors driving mobile marketing adoption and implementation in organizations.

5.3.3 Mobile marketing value creation - Mobile marketing is a rather new way of communicating and interacting with consumers. For that reason, there is a need for more studies on mobile marketing implementation for retailers. Of a certain interest for retailers are in-store and post-purchase mobile marketing, especially when integrated with other off-and on-line communications, products, packages etc.

5.2.4 Mobile marketing metrics - In order to evaluate the effectiveness and efficiency of mobile marketing practices, more empirically oriented research is needed to establish relevant metrics of mobile marketing, for example to align mobile marketing investments with overall results. 


\section{REFERENCES}

Alda's-Manzano, J., Ruiz-Mafe', C. \& Sanz-Blas, S. (2009): "Exploring individual personality factors as drivers of M-shopping acceptance”, Industrial Management \& Data Systems Vol. 109 No. 6, pp. 739-757.

Assael, H. (1987): Consumer behaviour and marketing action, Boston, Kent Publishing Company.

Atkin, C (1973): “Instrumental utilities and information seeking”, in: New Models for Mass Communication Research, Clarke, P. (ed.), Sage, London, pp. 205-242.

Atkin, C. \& Block, M. (1983): "Effectiveness of celebrity endorsers", Journal of Advertising Research, Vol 23 no 1, pp. 57-61.

Awuah, G. (2001): “A firm's competence development through its network of exchange relationships", Journal of Business \& Industrial Marketing, Vol. 16 No. 7, pp. 574-99.

Bakos, J. Y. (1997): "Reducing buyer search costs: Implications for electronic marketplaces", Management Science, Vol. 43 No. 12, pp. 1679-1692.

Balasubramanian, S., Peterson, R. A. \& Jarvenpaa, S. L. (2002): "Exploring the implications of mcommerce for markets and marketing”, Academy of Marketing Science Journal, Vol. 30 No. 4, pp. 348-361.

Barnes, S.J. (2002): “The mobile commerce value chain: Analysis and future developments”, International Journal of Information Management, Vol. 22, pp. 91-108.

Barutcu, S. (2007): “Attitudes towards mobile marketing tools: A study of Turkish consumers", Journal of Targeting, Measurement and Analysis for Marketing, Vol. 16, pp. 26-38.

Bauer, H. H, Reichardt, T., Barnes, S. J. \& Neumann, M. M. (2005): ”Driving consumer acceptance of mobile marketing: A theoretical framework and empirical study", Journal of Electronic Commerce Research, Vol. 6 No. 3, pp. 181-192.

Bellman, S., Potter, R. F., Treleaven-Hassard, S., Robinson, J. A. \& Varan, D. (2011): “The Effectiveness of Branded Mobile Phone Apps", Journal of Interactive Marketing, Vol. 25, pp. 191-200.

Beatty, S., E. \& Smith, S., M. (1987): "Xternal search effort: an investigation across several product categories", Journal of Consumer Research, Vol. 14 (June), pp. 83-95.

Bruner, G. C. \& Kumar, A. (2005): "Explaining consumer acceptance of handheld Internet devices”, Journal of Business Research, Vol. 58, pp. 553- 558. 
Brynjolfsson, E. \& Smith, M. D. (2000): "Frictionless Commerce? A comparison of Internet and conventional retailers", Management Science; Vol. 46 No. 4, pp. 563-585.

Brynjolfsson, E. Hu, Y. J. \& Smith, M. D. (2003): “Consumer surplus in the digital economy: Estimating the value of increased product variety at online booksellers", Management Science, Vol. 49 No. 11, pp. 1580-1596.

Bucklin, R. \& Sismeiro, C. (2003): A Model of Web Site Browsing Behavior Estimated on Clickstream Data, Journal of Marketing Research 249 Vol. XL, pp. 249-267.

Buellingen, F. \& Woerter, M. (2004): "Development perspectives, firm strategies and applications in mobile commerce", Journal of Business Research, Vol. 57, pp. 1402- 1408.

Calder, B. J. \& Sternthal, B. (1980): “Television commercial wearout: An information processing view", Journal of Marketing Research, Vol 17 No 2, pp. 173-186.

Carroll, A., Barnes, S. J., Scornavacca, E. \& Fletcher, K. (2007): “Consumer perceptions and attitudes towards SMS advertising: Recent evidence from New Zealand", International Journal of Advertising, Vol. 26 No. 1, pp. 79-98.

Chae, M., Kim, J., Kim, H., \& Ryu, H. (2002): “Information quality for mobile Internet services: A theoretical model with empirical validation”, Electronic Markets, Vol. 12 No. 1, pp. 38-46.

Chen, L. (2008): “A model of consumer acceptance of mobile payment”, International Journal of Mobile Communications, Vol. 6 No. 1, pp. 32-52.

Chen, L. D. \& Nath, R. (2004): “A framework for mobile business applications”, International Journal of Mobile Communications, Vol. 2 No 4, pp. 368-381.

Cheng, J. M.-S., Blankson, C., Wang, E. S.-T. \& Chen, L. S.-L. (2009): "Consumer attitudes and interactive digital advertising”, International Journal of Advertising, Vol. 28 No. 3, pp. 501-525.

Choi, Y. K., Hwang, J.-S. \& McMillan, S., J. (2008): “Gearing up for mobile advertising: A crosscultural examination of key factors that drive mobile messages home to consumers", Psychology \& Marketing, Vol. 25 No. 8, pp. 756-768.

Choi, J., Seol, H., Lee, S., Cho, H., \& Park, Y. (2008): “Customer satisfaction factors of mobile commerce in Korea”, Internet Research, Vol. 18 No. 3, pp. 313-335.

Constantinou, I. D., Papazafeiropoulou, A. \& Vendelø, M. T. (2009): "Does culture affect the adoption of advanced mobile services? A comparative study of young adults' perceptions in Denmark and the UK”, The DATA BASE for Advances in Information Systems, Vol. 40, No 4, pp. 132-147. 
Constantinou, I. D. \& Mahnke, V. (2010): “Consumer behaviour and mobile TV services: Do men differ from women in their adoption intentions", Journal of Electronic Commerce Research, Vol. 11 No. 2, pp. 127-139.

Court, D, Elzinga, D. Mulder, S. \& Vetvik, O. J. (2009): “The consumer decision journey”, McKinsey Quarterly.

Chowdhury, H. K., Parvin, N., Weitenberner, C. \& Becker, M. (2006): ”Consumer attitude toward mobile advertising in an emerging market: An empirical study", International Journal of Mobile Marketing, Vol. 1 No. 2, pp. 33-42.

Cyr, D., Head, M. \& Ivanov, A. (2006):” Design aesthetics leading to m-loyalty in mobile commerce", Information \& Management, Vol. 43, pp. 950-963.

Dai, H. \& Palvia, P. C. (2009): "Mobile commerce adoption in China and in the United States: a cross cultural study", The DATA BASE for Advances in Information Systems, Vol. 40 No 4, pp. 43-61.

Daugherty, T., Li, H. \& Biocca, F. (2008): “Consumer learning and the effects of virtual experience relative to indirect and direct product experience", Psychology \& Marketing, Vol. 25 No. 7, pp. 568-586.

Davis, F. D. (1989): "Perceived usefulness, perceived ease of use and user acceptance of information technology”, MIS Quarterly, Vol 12 No 3, pp. 319-339.

de Chernatony, L., Harris, F. \& Dall’Olmo Riley, F. (2000), “Added value: its nature, roles andsustainability”, European Journal of Marketing, Vol. 34 Nos 1/2, pp. 39-56.

Deng, Z., Lu, Y., Wei, K. K. \& Zhang, J. (2010): ’Understanding customer satisfaction and loyalty: An empirical study of mobile instant messages in China", International Journal of Information Management, Vol. 30, pp. 289-300.

Dholakia, R. R. \& Dholakia, N. (2004): "Mobility and markets: emerging outlines of mcommerce”, Journal of Business Research, Vol. 57, pp. 1391- 1396.

Dickinger, A. \& Kleijnen, M. (2008): “Coupons going wireless: Determinants of consumer intentions to redeem mobile coupons", Journal of Interactive Marketing, Vol. 22 No. 3, pp. 23-39.

Domke, D., Shah, D. V. \& Wackamn, D. B. (1998): “Media priming effects: Accessibility, association, and activation", International Journal of Public Opinion Research, Vol 10 No 1, pp. 51-74.

Edelman, D. C. (2010): "Branding in The Digital Age: You're Spending Your Money In All the Wrong Places", Harvard Business Review, Vol. 88 No. 12, pp. 62- 69. 
Figge, S. (2004): "Situation-dependent services: A challenge for mobile network operators", Journal of Business Research, Vol. 57, pp. 1416-1422.

Fishbein, M. \& Ajzen, I. (1975): Belief, Attitude, Intention and Behaviour; An Introduction to Theory and Research, Addison-Wesley, Reading, MA.

Frolick, M. N. \& Chen, L. (2004): “Assessing m-commerce opportunities”, Information Systems Management, Vol. 21 No 2, pp. 53-61.

Gao, Q., Rau, P.-L. P. \& Salvendy, G. (2009): "Perception of interactivity: Affects of four key variables in mobile advertising", International Journal of Human-Computer Interaction, Vol. 25 No. 6, pp. 479-505.

Goodhue, D.,L. \& Thompson R.,L. (1995): “Task-technology fit and individual performance", MIS Quarterly, Vol 19 No. 2, pp. 213-236.

Geysken, I., Gielens, K. \& Dekimpe, M. G. (2002): “The market valuation of Internet channel addition," Journal of Marketing, Vol 66 (April), 102-19.

Haghirian, P. \& Inoue, A. (2007): “An advanced model of consumer attitudes toward advertising on the mobile Internet”, International Journal of Mobile Communications, Vol. 5 No. 1, pp. 48-67.

Jarillo, J. C. (1988): “On strategic networks”, Strategic Management Journal, Vol. 9 No. 1, pp. 3141.

Jayawardhena, C., Kuckertz, A. \& Karjaluoto, H. \& Kautonen T. (2009): "Antecedents to permission based mobile marketing: an initial examination”, European Journal of Marketing, Vol. 43 No. 3/4, pp. 473-499.

Kannan, P. K., Chang, A.-M. and Whinston, A. B. (2001): "Wireless commerce: marketing issues and possibilities", Proceedings of the 34th Hawaii International Conference on System Sciences, Hawaii, IEEE, Piscataway, NJ, June, available http://ieeexplore.ieee.org/iel5/7255/20032/00927209.pdf

Kim, H., Chan, H. C. \& Gupta, S: (2007): "Value-based adoption of mobile Internet: An empirical investigation”, Decision Support Systems, Vol. 43 No. 1, pp. 111-126.

Kim, D. J., \& Hwang, Y. (2006): “A study of mobile Internet usage from utilitarian and hedonic user tendency perspectives", In Proceedings of the Twelfth Americas Conference on Information Systems.

Kim, M. J. \& Jun, J.W. (2008): “A case study of mobile advertising in South Korea: Personalization and digital multimedia broadcasting (DMB)", Journal of Targeting, Measurement and Analysis for 
Marketing”, Vol. 16, pp. 129 - 138.

Kleinen, M., de Reuter, K. \& Wetzels, M. (2009: “An assessment of value creation in mobile service delivery and the moderating role of time consciousness", Journal of Retailing, Vol 83 No 1, pp. 33-46.

Komulainen, H., Mainela, T., Tähtinen, J. \& Ulkuniemi, P. (2007): “Retailers' different value perceptions of mobile advertising service", International Journal of Service Industry Management, Vol. 18 No. 4, pp. 368-393.

Kondo, F. N. \& Nakahara, M. (2007): “Differences in customers' responsiveness to mobile direct mail coupon promotions”, International Journal of Mobile Marketing, Vol. 2 No 2, pp. 68-74.

Kumar, S. \& Zahn, C. (2003): "Mobile communications: Evolution and impact on business operations", Technovation, Vol. 23, pp. 515-520.

Lapierre, J. (1997), “What does value mean in business-to-business professional services?”, International Journal of Service Industry Management, Vol. 8 No. 5, pp. 377-97.

Laukkanen, T. (2007): “Internet vs mobile banking: Comparing customer value perceptions”, Business Process Management Journal Vol. 13 No. 6, pp. 788-797.

Lee, C., Cheng, H. K. \& Cheng, H. (2007): “An empirical study of mobile commerce in insurance industry", Task-technology fit and individual differences, Decision Support Systems, Vol. 43 No.1, pp. 95-110.

Leo Burnett \& Arc Worldwide (2011): “A mobile shopper research study". [Online]. Available at http://www.slideshare.net/LeoBurnettWorldwide/marketing-to-the-mobile-shopper>[Accessed 18 October, 2012].

Li, H. \& Stoller, B. (2007): "Parameters of mobile advertising: A field experiment", International Journal of Mobile Marketing, Vol. 2 No. 1, pp. 4-11.

Lin, H.-H. \& Wang, Y.-S. (2006): “An examination of the determinants of customer loyalty in mobile commerce contexts”, Information \& Management, Vol. 43 No. 3, 271-282.

Lynch, Jr. J. G. \& Ariely, D. (2000): “Wine online: Search costs affect competition on price, quality, and distribution”, Marketing Science, Vol. 19 No. 1, pp. 83-103.

Leppaäniemi, M., Karjaluoto, H. \& Salo, J. (2004), “The success factors of mobile advertising value chain”, E-Business Review, Vol. 4, pp. 93-97.

Machleit, K. A. \& Wilson R. D. (1988): "Emotional feelings and attitude toward the advertisement: 
The roles of brand familiarity and repetition.” Journal of Advertising, Vol 17 No 3, pp. 27-35.

Mahatanankoon, P., Wen, H. J., \& Lim, B. (2005): “Consumer-based m-commerce: exploring consumer perception of mobile applications”, Computer Standards \& Interfaces, Vol. 27 No. 4, pp. $347-357$.

Maheswaran, D. \& Chaiken, S. (1991): "Promoting systematic processing in low-involvement settings: Effect of incongruent information on processing and judgment”, Journal of Personality and Social Psychology, Vol 61 No 1, pp. 13-25.

Mahmoud, Q. H. \& Yu, L. (2006): "Havana agents for comparison shopping and location-aware advertising in wireless mobile environments", Electronic Commerce Research and Applications, Vol. 5, pp. 220-228.

Malladi, R. \& Agrawal, D. P. (2002): “Current and future applications of mobile and wireless networks", Communications of the ACM, Vol. 45 No. 10, pp. 144-146.

Mamaar, Z. (2003): “Commerce, E-Commerce, and M-Commerce: What Comes Next?”, Communications of the ACM, Vol. 46, No. 12, pp. 251-257.

Merisavo, M., Vesanen, J., Arponen, A. \& Kajalo, S. (2006): “The effectiveness of targeted mobile advertising in selling mobile services: An empirical study", International Journal of Mobile Communications, Vol, 4 No. 2, pp. 119-127.

Moe W. W.(2003): Buying, Searching, or Browsing: Differentiating between Online Shoppers Using In-Store Navigational Clickstream Journal of Consumer Psychology, Vol. 13, No. 1/2,pp. 2939.

Moorthy, S. \& Hawkins S. A. (2005): “Advertising repetition and quality perceptions”, Journal of Business Research, Vol 58 No 3, pp. 354-360.

Moynihan, B., Kabadayi, S. \& Kaiser, M. ( 2010): “Consumer acceptance of SMS advertising: A study of American and Turkish consumers”, International Journal of Mobile Communications, Vol. 8 No. 4, pp. 392-410.

Möller, K., Rajala, A. \& Svahn, S. (2005), "trategic business nets - their type and management", Journal of Business Research, Vol. 58 No. 9, pp. 1274-84.

Nysveen, H., Pedersen, P. E., \& Thorbjørnsen, H. (2005): “Intentions to use mobile services: Antecedents and cross-service comparisons", Journal of the Academy of Marketing Science, Vol. 33 No. 3, pp. 330-347. 
Nysveen, H., Pedersen, P. E. \& Berthon, P. (2005:1): "Mobilizing the brand : The effects of mobile services on brand relationships and main channel use", Journal of Service Research, Vol. 7 No. 3, pp. 257-276.

Okazaki, S. (2005): "Mobile advertising adoption by multinationals", Internet Research, Vol. 15 No. 2, pp. 160-180.

Okazaki, S. (2007:1): "Exploring Gender Effects in a Mobile Advertising Context: On the Evaluation of Trust, Attitudes, and Recall”, Sex Roles, Vol. 57, pp. 897-908.

Okazaki, S. (2007:2): "Lessons learned from i-mode: What makes consumers click wireless banner ads?", Computers in Human Behaviour, Vol. 23, pp. 1692-1719.

Okazaki, S., Katsukura, A., \& Nishiyama, M. (2007): "How mobile advertising works: The role of trust in improving attitudes and recall”, Journal of Advertising Research, Vol. 47 No 2, pp. 165178.

Okazaki, S. \& Hirose, M. (2009): "Effects of displacement-reinforcement between traditional media, PC Internet and mobile Internet: A quasi experiment in Japan”, International Journal of Advertising, Vol. 28 No. 1, pp. 77-104.

Okazaki, S. \& Romero, J. (2010): “Online media rivalry: A latent class model for mobile and PC Internet users", Online Information Review, Vol. 34 No. 1, pp. 98-114.

Okazaki, S. \& Taylor, C. R. (2008): "What is SMS advertising and why do multinationals adopt it? Answers from an empirical study in European markets", Journal of Business Research, Vol. 61 No. 1, pp. 4-12.

Parasuraman, A. (1997), "Reflections on gaining competitive advantage through customervalue", Academy of Marketing Science, Vol. 25 No. 2, pp. 154-61.

Park, J. \& SuJin, Y. (2006): “The moderating role of consumer trust and experiences: Value driven usage of mobile technology", International Journal of Mobile Marketing, Vol, 1 No. 2, pp. 24-32.

Peters, C., Amato, C., H. \& Hollenbeck, C., R. (2007): “An exploratory investigation of consumers' perceptions of wireless advertising”, Journal of Advertising, Vol. 36, No.4, pp. 129-145.

Pham, M. T. \& Vanhuele, M. (1997): “Analyzing the memory impact of advertising fragments”, Marketing Letters, Vol 8 No 4, pp. 407-417.

Pilström, M. \& Brusch, G., J. (2008): “Comparing the perceived value of information and enter- 
tainment mobile services”, Psychology \& Marketing, Vol. 25(8): 732-755.

Porter, M. E. (1985): The Competitive Advantage: Creating and Sustaining Superior Performance, N.Y., Free Press.

Prahalad, C. K. \& Ramaswamy, C. K. (2003): The New Frontier of Experience Innovation, Sloan Management Review, Summer

Rau, P.-L. P., Zhang, T., Shang, X. \& Zhou, J. (2011): “Content relevance and delivery time of SMS advertising”, International Journal of Mobile Communications, Vol. 9 No. 1, pp. 19-38.

Rettie, R., Grandcolas, U. \& Deakins, B. (2005): "Text message advertising: response rates and branding effects", Journal of Targeting, Measurement and Analysis for Marketing, Vol. 13 No. 4, pp. 304-312.

Rogers, E. (1995): Diffusion of Innovations, 4th ed., Free Press, New York, NY.

Rusbult, Caryl E. (1980), "Satisfaction and Commitment in Friendships," Representative Research in Social Psychology, Vol. 11, pp. 96-105.

Salo, J., Sinisalo, J. \& Karjaluoto, H. (2008): “Intentionally developed business network for mobile marketing: a case study from Finland”, Journal of Business \& Industrial Marketing, Vol. 23 No. 7, pp. 497-506.

Scharl, A., Dickinger, A. \& Murphy, J. (2005); "Diffusion and success factors of mobile marketing”, Electronic Commerce Research and Applications, Vol. 4 No. 2, pp. 159-173.

Sengupta, J. \& Johar, G. V. (2002): "Effects of inconsistent attribute information on the predictive value of product attitudes: Toward a resolution of opposing perspectives", Journal of Consumer Research, Vol 29 No 2, pp. 39-56.

Shankar, V. \& Balusbramanian, S. (2009): "Mobile marketing: A synthesis and prognosis”, Journal of Interactive Marketing, Vol. 23 No. 2, pp. 118-129.

Shankar, V., Venkatesh, A., Hofacker, C. \& Naik, P. (2010): "Mobile marketing in the retailing environment: Current insights and future research avenues", Journal of Interactive Marketing, Vol. 24 No. 2, pp. 111-120.

Sharma, C., Herzog, J. \& Melfi, V. (2008): “A five -points measurement framework for mobile advertising", International Journal of Mobile Marketing, Vol. 3 No. 1, pp. 4-11.

Stewart, D., Pechmann, C., Ratneshwar, S., Stroud, J. \& Bryant, B. (1985): “Methodological and Theoretical Foundations of Advertising Copy Testing: A Review," Current Issues and Research in 
Advertising, Vol 2, pp. 1-78.

Sultan, F. \& Rohm, A. J. (2008): "How to market to generation m(obile)", MIT Sloan Management Review, Vol. 49 No. 4, pp. 35-41.

Thibaut, J. W. \& Kelley H. H. (1959): The Social Psychology of Groups, New York, John Wiley.

Thompson, M. (2006): “Human brands: Investigating antecedents to consumers' strong attachments to celebrities", Journal of Marketing, Vol 70 No 3, pp. 104-119.

Tsang, M. M., Ho, S., \& Liang, T. (2004); “Consumer attitudes toward mobile advertising: An empirical study”, International Journal of Electronic Commerce, Vol. 8 No. 3, pp. 65-78.

Turel, O., Serenko, A. \& Bontis, N. (2007): “User acceptance of wireless short messaging services: Deconstructing perceived value", Information \& Management, Vol. 44, pp. 63-73.

Ulaga, W. (2003), "Capturing value creation in business relationships: a customer perspective”, Industrial Marketing Management, Vol. 32 No. 8, pp. 677-93.

Varnali, K. and Toker, A. (2010): "Mobile marketing research: The-state-of-the-art", International Journal of Information Management, Vol. 30, pp. 144-151.

Wais, J. S., \& Clemons, E. K. (2008): “Understanding and implementing mobile social advertising”, International Journal of Mobile Marketing, Vol. 3 No. 1, pp. 12-18.

Walter, A., Ritter, T. \& Gemünden, H-G. (2001), "Value creation in buyer-seller relationships: Theoretical considerations and empirical results from a supplier's perspective”, Industrial Marketing Management, Vol. 30 No. 4, pp. 365-77.

Wang, A. (2006): “Advertising engagement, a driver of message involvement on message effects”, Journal of Advertising Research, Vol. 46, pp. 355-368.

Wang, A. \& Acar, S., A. (2006): “Information search and mobile promotions", International Journal of Mobile Marketing, Vol. 1 No. 2, pp. 80-87. 
Wang, A. (2007): “Branding over mobile and Internet advertising, the cross-media effect", International Journal of Mobile Marketing, Vol. 2 No. 1, pp. 34-42.

Watson, R. T., Pitt, L. F., Berthon, P., \& Zinkhan, G. M. (2002). U-Commerce: Extending The Universe Of Marketing. Journal of the Academy of Marketing Science, 30 (4), 333-347.

Watson, R. T., Pitt, L. F., Berthon, P., \& Zinkhan, G. M. (2004). Marketing in the Age of the Network: From Marketplace to U-space. Business Horizons, 4 (6), 33-40.

Wen, H. J. \& Mahatanankoon, P. (2004): “M-commerce operation modes and applications”, International Journal of Electronic Business, Vol. 2 No. 3, pp. 301.

Wickens, C. D. (1984): "Processing resources in attention." In Parasuraman, R. \& Davies, D. R. (Eds.), Varieties of Attention (pp. 63-102), New York, Academic Press.

Xu, D. J. (2006/2007): “The influence of personalization in affecting consumer attitudes toward mobile advertising in China”, The Journal of Computer Information Systems, Vol. 47 No. 2, pp. 920.

Xu, H., Lou, X., R., Carroll, J. M. \& Rosson, M. B (2011): “The personalization privacy paradox: An exploratory study of decision making process for location-aware marketing”, Decision Support Systems, Vol. 51, pp. 42-52.

Xu, H., Oh, L. B. \& Teo, H. H. (2009): "Perceived effectiveness of text vs. multimedia locationbased advertising messaging", International Journal of Mobile Communications, Vol. 7, No. 2, 154-177.

Yang, K., \& Jolly, L. D. (2006): "Value-added mobile data services: The antecedent effects of consumer value on using mobile data services”, International Journal of Mobile Marketing, Vol. 1 No. 2, pp. 11-17.

Yeh, J.-T. \& Lin, C.-L. (2010): "Measuring the effectiveness of advertisements sent via mobile phone: Implications of the appeal, endorser, and involvement model and purchasing behaviour", Social Behaviour and Personality, Vol. 38 No. 2, pp. 249-256.

Zeithaml, V.A. (1988): “Consumer perceptions of price, quality, and value: a means-end model and synthesis of evidence”, Journal of Marketing, Vol. 52 No. 1, pp. 2-22.

[1] http://mmaglobal.com/wiki/mobile-marketing (2011-12-21)

[2] http://www.youtube.com/watch?v=nJVoYsBym88 (2012-08-21) 


\section{APPENDIX 1}

A. Table 1. Studies of consumer perceived value of mobile marketing

\begin{tabular}{|c|c|c|c|}
\hline Research theme & Author & Theory & $\begin{array}{l}\text { Type of } \\
\text { study }\end{array}$ \\
\hline \multirow[t]{4}{*}{$\begin{array}{l}\text { Mobile service } \\
\text { adoption }\end{array}$} & $\begin{array}{l}\text { Constantinou et } \\
\text { al (2009) }\end{array}$ & $\begin{array}{l}\text { Reasoned based choice theory, perceived value \& } \\
\text { cultural differences in adoption intention }\end{array}$ & Quantitative \\
\hline & $\begin{array}{l}\text { Constantinou \& } \\
\text { Mahnke (2010) }\end{array}$ & $\begin{array}{l}\text { Reasoned based choice theory, perceived value \& } \\
\text { gender differences in adoption intention }\end{array}$ & Quantitative \\
\hline & Kim et al (2007) & Perceived value \& extended TAM & Quantitative \\
\hline & Turel et al (2007) & Perceived value \& TRA & Quantitative \\
\hline $\begin{array}{l}\text { Mobile marketing } \\
\text { adoption }\end{array}$ & $\begin{array}{l}\text { Dai \& Palvia } \\
(2009)\end{array}$ & $\begin{array}{l}\text { Personal predispositions, extended TAM, perceived } \\
\text { value, compatibility \& subjective norm }\end{array}$ & Quantitative \\
\hline $\begin{array}{l}\text { Mobile } \\
\text { technology use }\end{array}$ & $\begin{array}{l}\text { Park \& SuJin } \\
(2006)\end{array}$ & $\begin{array}{l}\text { Consumer values, attitudes and behavioural intentions, } \\
\text { technology trust, technology experience, (Elaboration- } \\
\text { Likelihood Model (ELM) and Heuristic-Systematic } \\
\text { Processing Model (HSM)) }\end{array}$ & Quantitative \\
\hline \multirow[t]{2}{*}{$\begin{array}{l}\text { Mobile service } \\
\text { use }\end{array}$} & $\begin{array}{l}\text { Kim \& Hwang } \\
(2006)\end{array}$ & $\begin{array}{l}\text { Personal predispositions and application value } \\
\text { tendencies, user \& media gratification theory, service } \\
\text { quality }\end{array}$ & Quantitative \\
\hline & $\begin{array}{l}\text { Yang \& Jolly } \\
(2006)\end{array}$ & Consumer values, perceived value, TRA, TPB & Quantitative \\
\hline \multirow[t]{2}{*}{$\begin{array}{l}\text { Mobile marketing } \\
\text { use }\end{array}$} & $\begin{array}{l}\text { Kleinen et al } \\
(2009)\end{array}$ & $\begin{array}{l}\text { Personal predispositions, perceived value, intentions } \\
\text { to use, }\end{array}$ & Quantitative \\
\hline & Laukkanen & Benefits of Internet and mobile bank & Qualitative \\
\hline
\end{tabular}




\begin{tabular}{|c|c|c|c|}
\hline & $(2007)$ & & \\
\hline & $\begin{array}{l}\text { Mahatanankoon } \\
\text { et al (2005) }\end{array}$ & $\begin{array}{l}\text { Values of mobile marketing and mobile marketing } \\
\text { operation modes }\end{array}$ & Quantitative \\
\hline & Xu et al (2011) & $\begin{array}{l}\text { Perceived value \& behavioural intentions, personal } \\
\text { predispositions, technology experience }\end{array}$ & Quantitative \\
\hline \multirow[t]{2}{*}{$\begin{array}{l}\text { Mobile service } \\
\text { loyalty }\end{array}$} & Deng et al (2010) & $\begin{array}{l}\text { Media formats, media uses and gratification (Internet } \\
\text { advertising), advertising effectiveness, technology } \\
\text { experiences, personal predispositions, TRA } \\
\text { Perceived value, service quality, customer satisfaction, } \\
\text { trust, loyalty \& personal predispositions, technology } \\
\text { experience }\end{array}$ & Quantitative \\
\hline & $\begin{array}{l}\text { Pilström \& } \\
\text { Brusch (2008) }\end{array}$ & Perceived value \& customer loyalty & Quantitative \\
\hline $\begin{array}{l}\text { Mobile marketing } \\
\text { loyalty }\end{array}$ & $\begin{array}{l}\text { Lin \& Wang } \\
(2006)\end{array}$ & $\begin{array}{l}\text { Perceived value, customer satisfaction, technology } \\
\text { experience, trust \& loyalty }\end{array}$ & Quantitative \\
\hline
\end{tabular}

B. Table 2. Studies of consumer perceived benefits and sacrifices of mobile marketing 


\begin{tabular}{|c|c|c|c|}
\hline Research theme & Author & Theory & $\begin{array}{l}\text { Type of } \\
\text { study }\end{array}$ \\
\hline \multirow[t]{6}{*}{$\begin{array}{l}\text { Mobile } \\
\text { marketing } \\
\text { adoption }\end{array}$} & $\begin{array}{l}\text { Alda's-Manzano } \\
\text { et al (2009) }\end{array}$ & $\begin{array}{l}\text { Personal predispositions \& TAM, attitude } \\
\text { affinity,compatibility }\end{array}$ & Quantitative \\
\hline & $\operatorname{Amin}(2008)$ & Extended TAM & Quantitative \\
\hline & Kim et al (2009) & $\begin{array}{l}\text { Extended TAM, attitudes toward mobile } \\
\text { communication, subjective norm }\end{array}$ & Quantitative \\
\hline & Lu \& Su (2008) & $\begin{array}{l}\text { Extended TAM, mobile technology experience, } \\
\text { compatibility }\end{array}$ & Quantitative \\
\hline & $\begin{array}{l}\text { Muk (2007) } \\
\text { Roach (2009) }\end{array}$ & $\begin{array}{l}\text { Attributes of innovation for adoption, TRA } \\
\text { Attributes of innovation for adoption }\end{array}$ & $\begin{array}{l}\text { Quantitative } \\
\text { Quantitative }\end{array}$ \\
\hline & $\begin{array}{l}\text { Zhang \& Mao } \\
(2008)\end{array}$ & $\begin{array}{l}\text { TAM, user \& media gratification theory, trust, } \\
\text { subjective norm }\end{array}$ & Quantitative \\
\hline \multirow[t]{5}{*}{$\begin{array}{l}\text { Mobile } \\
\text { marketing use }\end{array}$} & Barutcu (2007) & $\begin{array}{l}\text { Personal predispositions, technology experiences, } \\
\text { mobile marketing tools classification, attitudes }\end{array}$ & Quantitative \\
\hline & $\begin{array}{l}\text { Bauer et al } \\
(2005)\end{array}$ & $\begin{array}{l}\text { Personal predispositions, perceived risk and utility } \\
\text { (perceived value), TRA }\end{array}$ & Quantitative \\
\hline & $\begin{array}{l}\text { Carroll et al } \\
(2007)\end{array}$ & Consumer acceptance of m-marketing & $\begin{array}{l}\text { Qualitative } \\
\& \\
\text { quantitative }\end{array}$ \\
\hline & $\begin{array}{l}\text { Cheng et al } \\
(2009)\end{array}$ & $\begin{array}{l}\text { Media uses and gratification (Internet advertising), } \\
\text { advertising effectiveness, attitudes }\end{array}$ & Quantitative \\
\hline & Choi et al (2008) & Culture, media uses and gratification, advertising & Quantitative \\
\hline
\end{tabular}




\begin{tabular}{|c|c|c|}
\hline & $\begin{array}{l}\text { effectiveness, attitudes (Internet advertising) and } \\
\text { behavioural intentions }\end{array}$ & \\
\hline $\begin{array}{l}\text { Chowdhury et al } \\
(2006)\end{array}$ & $\begin{array}{l}\text { Media uses and gratification (Internet advertising), } \\
\text { advertising effectiveness, attitudes }\end{array}$ & Quantitative \\
\hline $\begin{array}{l}\text { Dickinger \& } \\
\text { Kleijnen (2008) } \\
\text { Gao et al (2009) } \\
\text { Haghirian \& } \\
\text { Inoue (2007) }\end{array}$ & $\begin{array}{l}\text { TAM, TPB, previous category use } \\
\text { Perceived interactivity, mobile design features. } \\
\text { advertising effectiveness } \\
\text { Consumer values, mobile advertising values, media } \\
\text { uses and gratification (Internet advertising), } \\
\text { advertising effectiveness, attitudes and behavioural } \\
\text { intentions }\end{array}$ & Quantitative \\
\hline $\begin{array}{l}\text { Jayawardhena et } \\
\text { al (2009) } \\
\text { Moynihan et al } \\
(2010) \\
\text { Okazaki } \\
(2007: 1) \\
\text { Okazaki } \\
(2007: 2)\end{array}$ & $\begin{array}{l}\text { Trust, mobile marketing experience, perceived risk, } \\
\text { behaviour/permission } \\
\text { TRA, TBP, perceived knowledge, self efficacy, trust } \\
\text { Gender, technology experience, trust, advertising } \\
\text { effectiveness, attitude and behavioural intentions } \\
\text { Personal predispositions, media uses and gratification } \\
\text { (Internet advertising), advertising effectiveness, } \\
\text { attitudes and behavioural intentions }\end{array}$ & $\begin{array}{l}\text { Quantitative } \\
\text { Quantitative }\end{array}$ \\
\hline $\begin{array}{l}\text { Okazaki et al } \\
(2007)\end{array}$ & $\begin{array}{l}\text { Trust, advertising effectiveness, attitude and } \\
\text { behavioural intentions }\end{array}$ & Quantitative \\
\hline $\begin{array}{l}\text { Okazaki \& } \\
\text { Hirose (2009) }\end{array}$ & $\begin{array}{l}\text { Niche theory, media uses and gratification, enduring } \\
\text { involvement, satisfaction, attitude, loyalty }\end{array}$ & Quantitative \\
\hline
\end{tabular}




\begin{tabular}{|c|c|c|c|}
\hline & $\begin{array}{l}\text { Okazaki \& } \\
\text { Romeo (2010) }\end{array}$ & $\begin{array}{l}\text { Media displacement theory, media complementarity } \\
\text { theory and media richness theory }\end{array}$ & Quantitative \\
\hline & $\begin{array}{l}\text { Peters et al } \\
(2007)\end{array}$ & Media uses and gratification, TRA & Qualitative \\
\hline & Rau et al (2011) & $\begin{array}{l}\text { Information processing (content relevance, delivery } \\
\text { time and frequency of messages), advertising } \\
\text { effectiveness, attitudes, behavioural intentions }\end{array}$ & Quantitative \\
\hline & $\begin{array}{l}\text { Tsang et al } \\
(2004)\end{array}$ & $\begin{array}{l}\text { Media uses and gratification (Internet advertising), } \\
\text { TRA }\end{array}$ & Quantitative \\
\hline & $\begin{array}{l}\text { Wais \& Clemons } \\
(2008)\end{array}$ & $\begin{array}{l}\text { Social marketing, viral marketing/word of mouth, } \\
\text { attitudes }\end{array}$ & Quantitative \\
\hline & $\begin{array}{l}\text { Wang \& Acar } \\
(2006)\end{array}$ & $\begin{array}{l}\text { Exploratory information search behaviour, consumer } \\
\text { attitudes towards Internet and mobile promotions }\end{array}$ & Quantitative \\
\hline & $\mathrm{Xu}(2006)$ & $\begin{array}{l}\text { Media uses and gratification (Internet advertising), } \\
\text { advertising effectiveness, personalization, TAM, TPB }\end{array}$ & Quantitative \\
\hline \multirow[t]{3}{*}{$\begin{array}{l}\text { Mobile } \\
\text { marketing } \\
\text { loyalty }\end{array}$} & Chae et al (2002) & $\begin{array}{l}\text { User \& media gratification theory, information quality, } \\
\text { customer satisfaction. Loyalty }\end{array}$ & Quantitative \\
\hline & Choi et al (2008) & $\begin{array}{l}\text { Internet and mobile Internet benefits and costs, } \\
\text { customer satisfaction \& loyalty }\end{array}$ & Quantitative \\
\hline & Cyr et al (2006) & Extended TAM, design aestetics \& customer loyalty & Quantitative \\
\hline
\end{tabular}


C. Table 3. Studies of the value of mobile marketing for retailers

\begin{tabular}{|c|c|c|c|}
\hline $\begin{array}{c}\text { Research } \\
\text { theme }\end{array}$ & Author & Theory & $\begin{array}{l}\text { Type of } \\
\text { study }\end{array}$ \\
\hline \multirow[t]{4}{*}{$\begin{array}{l}\text { The value of } \\
\text { mobile } \\
\text { marketing for } \\
\text { retailers }\end{array}$} & $\begin{array}{l}\text { Komulainen et al } \\
(2007)\end{array}$ & Perceived value, BTB and network value creation & Qualitative \\
\hline & Lee et al (2007) & $\begin{array}{l}\text { Insurance agents task characteristics, mobile technology } \\
\text { characteristics, personal predispsitions }\end{array}$ & Quantitative \\
\hline & Okazaki (2005) & Adoption of innovations in organizations & Quantitative \\
\hline & $\begin{array}{l}\text { Okazaki \& Taylor } \\
(2008)\end{array}$ & Adoption of innovations in organizations & Quantitative \\
\hline \multirow[t]{5}{*}{$\begin{array}{l}\text { The improved } \\
\text { value of mobile } \\
\text { marketing }\end{array}$} & $\begin{array}{l}\text { Bellman et al } \\
(2011)\end{array}$ & $\begin{array}{l}\text { Advertising effectiveness, ELM, media uses and } \\
\text { gratification, advertising planner grid, perceptions and } \\
\text { information processing, }\end{array}$ & Quantitative \\
\hline & $\begin{array}{l}\text { Kim \& Jun } \\
(2008)\end{array}$ & $\begin{array}{l}\text { Mobile marketing and advertising classification, } \\
\text { advertising effectiveness }\end{array}$ & $\begin{array}{l}\text { Qualitative } \\
\& \\
\text { qualitative }\end{array}$ \\
\hline & $\begin{array}{l}\text { Kondo \& } \\
\text { Nakahara (2007) }\end{array}$ & Behavioural effect of advertising/direct marketing & Quantitative \\
\hline & $\begin{array}{l}\text { Li \& Stoller } \\
(2007)\end{array}$ & Advertising effectiveness (Internet advertising) & Quantitative \\
\hline & $\begin{array}{l}\text { Merisavo et al } \\
(2006)\end{array}$ & Advertising effectiveness, related products & Quantitative \\
\hline
\end{tabular}




\begin{tabular}{|c|c|c|c|}
\hline & $\begin{array}{l}\text { Nysveen et al } \\
(2005)\end{array}$ & $\begin{array}{l}\text { Investment and Interdependence Models of } \\
\text { Relationships, Channel Addition Usage }\end{array}$ & Quantitative \\
\hline & Rettie et al (2005) & $\begin{array}{l}\text { Advertising effectiveness, traditional and direct } \\
\text { marketing }\end{array}$ & Quantitative \\
\hline & $\begin{array}{l}\text { Wang (2007) } \\
\text { Yeh \& Lin (2010) }\end{array}$ & $\begin{array}{l}\text { Integrated marketing, Multiple Resource Theory (MRT) } \\
\text { on inter-media comparison, information processing } \\
\text { Advertising effectiveness, advertising appeal and } \\
\text { endorser affects on advertising effects, information } \\
\text { processing, }\end{array}$ & $\begin{array}{l}\text { Quantitative } \\
\text { Quantitative }\end{array}$ \\
\hline \multirow[t]{4}{*}{$\begin{array}{l}\text { Realizing } \\
\text { potential value } \\
\text { in mobile } \\
\text { marketing }\end{array}$} & Salo et al (2008) & $\begin{array}{l}\text { Mobile marketing campaign process, mobile marketing } \\
\text { value chain/network/actors, Intentionally Developed } \\
\text { Business Networks (IDBN) }\end{array}$ & Qualitative \\
\hline & $\begin{array}{l}\text { Scharl et al } \\
(2005)\end{array}$ & $\begin{array}{l}\text { Mobile message } \& \text { media success factors, TRA, TAM, } \\
\text { advertising effectiveness }\end{array}$ & $\begin{array}{l}\text { Qualitative } \\
\& \\
\text { quantitative }\end{array}$ \\
\hline & $\begin{array}{l}\text { Sultan \& Rohm } \\
(2005)\end{array}$ & $\begin{array}{l}\text { Media characteristics, advertising effectiveness, mobile } \\
\text { value chain }\end{array}$ & Qualitative \\
\hline & $\begin{array}{l}\text { Sultan \& Rohm } \\
(2008)\end{array}$ & $\begin{array}{l}\text { Media usage characteristics, attitudes towards mobile } \\
\text { communications, personal predispositions }\end{array}$ & Quantitative \\
\hline
\end{tabular}


D. Table 4. Studied technology, services and applications

\begin{tabular}{|c|c|c|}
\hline Research category & Technology, service, application & $\begin{array}{l}\text { No. of } \\
\text { studies }\end{array}$ \\
\hline \multirow[t]{4}{*}{ Consumer perceived value } & Mobile devices & 1 \\
\hline & Mobile services & 7 \\
\hline & Mobile advertising & 2 \\
\hline & $\begin{array}{l}\text { Mobile distance channels } \\
\text { Mobile marketing (several tools) }\end{array}$ & $\begin{array}{l}4 \\
1\end{array}$ \\
\hline \multirow[t]{3}{*}{$\begin{array}{l}\text { Consumer perceived benefits and } \\
\text { sacrifices }\end{array}$} & Mobile services & 1 \\
\hline & Mobile advertising & 23 \\
\hline & $\begin{array}{l}\text { Mobile distance channels } \\
\text { Mobile marketing (several tools) }\end{array}$ & 7 \\
\hline \multirow[t]{2}{*}{$\begin{array}{l}\text { The value of mobile marketing for } \\
\text { retailers }\end{array}$} & Mobile advertising & 3 \\
\hline & Mobile marketing (internal) & 1 \\
\hline \multirow[t]{2}{*}{$\begin{array}{l}\text { The improved value of mobile } \\
\text { marketing }\end{array}$} & Mobile advertising & 8 \\
\hline & Mobile marketing (CRM) & 1 \\
\hline $\begin{array}{l}\text { Realizing potentials in mobile } \\
\text { marketing }\end{array}$ & Mobile advertising & 4 \\
\hline Total & & 64 \\
\hline
\end{tabular}




\section{creation}

8. Figures

Consumers

\section{Retailers}

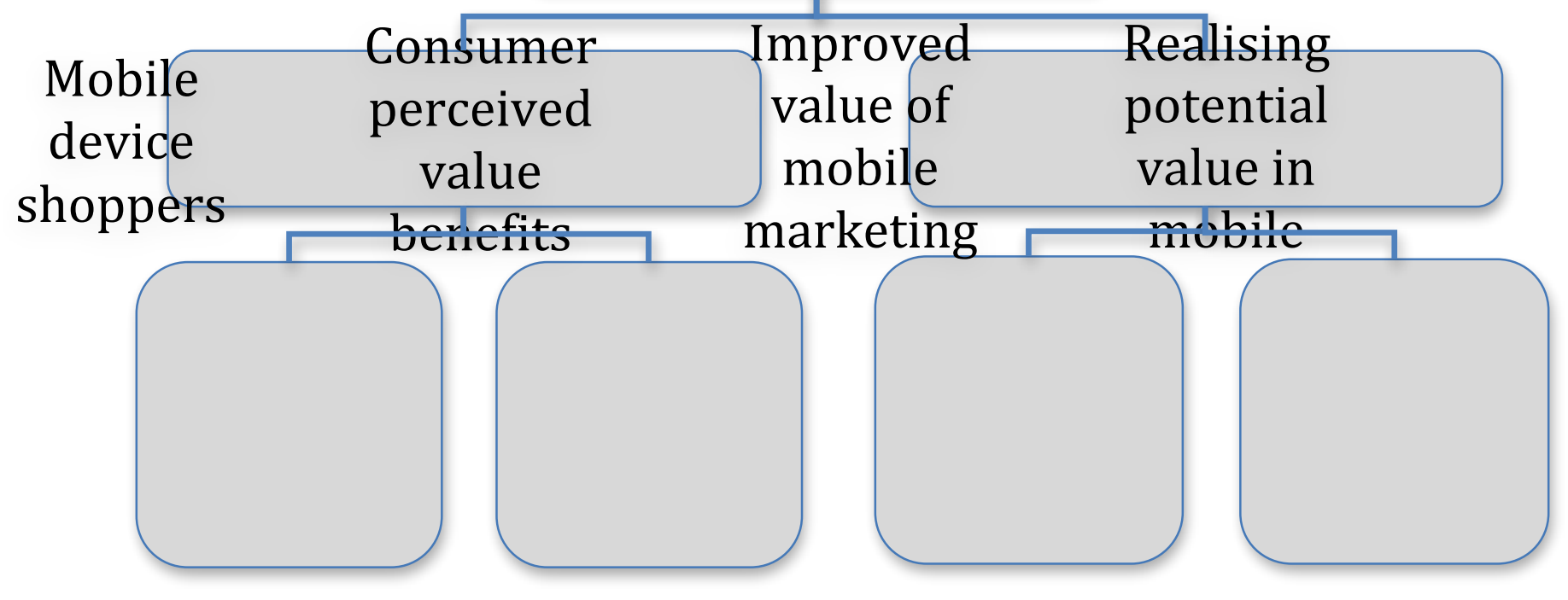

Figure 1: Discussion topology 